einstein

Official Publication of the Instituto Israelita

de Ensino e Pesquisa Albert Einstein

ISSN: 1679-4508 | e-ISSN: 2317-6385

\title{
Effective vancomycin concentrations in children: a cross-sectional study
}

\author{
Concentrações efetivas de vancomicina em crianças: \\ estudo transversal \\ Geisa Cristina da Silva Alves ${ }^{1,2}$, Farah Maria Drumond Chequer', Cristina Sanches' \\ ${ }^{1}$ Universidade Federal de São João del-Rei, Divinópolis, MG, Brazil. \\ 2 Universidade de Itaúna, Itaúna, MG, Brazil.
}

DOI: 10.31744/einstein_journal/2019A04396

\section{ABSTRACT}

Objective: Analyze the microbiological effectiveness, based on the pharmacokinetics/ pharmacodynamics correlation of vancomycin in pediatric patients, and to propose dose adjustment. Methods: This is an observational, cross-sectional study, conducted in a pediatric hospital, over a 1-year period (2016 to 2017). Children of both sexes, aged 2 to 12 years, were included in the study; burn children, and children in renal replacement therapy were excluded. For the pharmacokinetic analysis, two samples of $2 \mathrm{~mL}$ of whole blood were collected, respecting the 2-hour interval between each withdrawal. Results: Ten pediatric patients with median age of 5.5 years and interquartile range (IOR) of $3.2-9.0$ years, median weight of $21 \mathrm{~kg}$ (IOR: $15.5-24.0 \mathrm{~kg}$ ) and median height of $112.5 \mathrm{~cm}$ (IOR: $95-133 \mathrm{~cm}$ ), were included. Only one child achieved trough concentrations between $10 \mu \mathrm{g} / \mathrm{mL}$ and $15 \mu \mathrm{g} / \mathrm{mL}$. Conclusion: The empirical use of vancomycin in the children studied did not achieve the therapeutic pharmacokinetic/ pharmacodynamic target for minimum inhibitory concentration of $1 \mu \mathrm{g} / \mathrm{mL}$.

Keywords: Microbial sensitivity tests; Pharmacokinetics; Pharmacologic actions; Vancomycin; Child

How to cite this article:

Alves GC, Chequer FM, Sanches C. Effective vancomycin concentrations in children: a cross-sectional study. einstein (São Paulo). 2019;17(1):eA04396. http://dx.doi.org/ 10.31744/einstein journal/2019A04396

Corresponding author: Geisa Cristina da Silva Alves

Rua Sebastião Gonçalves Coelho, 400 building $\mathrm{E}$ - Chanadour

Zip code: 35501-296 - Divinópolis, MG, Brazil

Phone: (55 37) 3690-4450

E-mail: geisa.cristina@gmail.com

Received on:

Jan 23, 2018

Accepted on:

June 12, 2018

Conflict of interest:

none.

Copyright 2019

(c) $\mathrm{BY}$

This content is licensed

under a Creative Commons

Attribution 4.0 International License.

\section{RESUMO}

Objetivo: Analisar a efetividade microbiológica considerando a correlação farmacocinética/ farmacodinâmica de vancomicina em crianças e propor uma estimativa de ajuste na dose. Métodos: Trata-se de um estudo observacional, transversal, realizado em hospital pediátrico, no período de 1 ano (2016 a 2017). Foram inclú́das crianças de 2 a 12 anos de ambos os sexos, tendo sido exclú́das crianças queimadas ou submetidas à terapia renal substitutiva. Para análise farmacocinética, foram coletadas duas amostras de $2 \mathrm{~mL}$ de sangue total, respeitando 0 intervalo de 2 horas entre cada coleta. Resultados: Foram incluídos dez pacientes pediátricos com idade de 5,5 anos (mediana) e intervalo interquartil (IO) de 3,2-9,0 anos, peso de $21 \mathrm{~kg}$ (mediana; IQ: $15,5-24,0 \mathrm{~kg}$ ) e altura de $112,5 \mathrm{~cm}$ (mediana; I0: $95-133 \mathrm{~cm}$ ). Apenas uma criança alcançou concentrações mínimas entre $10 \mu \mathrm{g} / \mathrm{mL}$ e $15 \mu \mathrm{g} / \mathrm{mL}$. Conclusão: A utilização empírica de vancomicina na população de crianças não alcançou 0 alvo farmacocinético/farmacodinâmico terapêutico para concentração inibitória mínima de $1 \mu \mathrm{g} / \mathrm{mL}$.

Descritores: Testes de sensibilidade microbiana; Farmacocinética; Ações farmacológicas; Vancomicina; Criança

\section{INTRODUCTION}

In developing countries, the determination of regimen of antimicrobials in children is supported by empirical protocols, based on the etiological knowledge 
of infections, expert consensus, and linear reduction of adult doses. $^{(1)}$

Patients who are critically ill, including pediatric patients, present age-related physiological changes, with consequent pharmacokinetic (PK) instability to antimicrobials, and may present changes in the apparent volume of distribution ( $\mathrm{Vd})$, plasma clearance, and reduced biological half-life. ${ }^{(2,3)}$

In addition, the therapeutic monitoring of antimicrobials is relevant and necessary to optimize pharmacotherapy and the selection of resistant bacteria, as well as to minimize the sub-therapeutic or toxic concentrations. ${ }^{(2-6)}$ Therefore, both safety and efficacy of antimicrobials related to the doses administered in children are questionable, since there are few studies conducted in this population on these therapeutic aspects. $^{(2,4,5,7)}$

\section{OBJECTIVE}

To analyze the microbiological effectiveness by means of the pharmacokinetic/pharmacodynamic correlation of vancomycin in pediatric patients and to propose a dose adjustment.

\section{METHODS}

This study was approved by the Ethics Committee on Research Involving Human Beings, protocols CAAE: 44803815.7.0000.5545, and SIGED 3388/22712016, on March 17, 2016. The entire study was conducted in accordance with resolution 466/2012. Informed consent was obtained from every individual participants included in the study. The children included were invited to participate in the study and their legal guardians signed an Informed Consent, as well as an Agreement Term.

This is an observational, cross-sectional study conducted at a pediatric hospital in the Mid-Western region of the State of Minas Gerais, Brazil. Ten children on vancomycin, from March 2016 to March 2017, boys and girls, aged 2 to 12 years, were included in the study. Burn children and those undergoing renal replacement therapy were excluded.

The empirical dose of vancomycin used at the organization is 10 to $20 \mathrm{mg} / \mathrm{kg}$, according to guideline recommendations, to maintain adequate plasma concentrations. $^{(6)}$

The variables of interest were obtained from the records of the children, comprising age, sex, weight, height and body mass index (BMI), presence of wounds, date of admission, hospitalization unit, first day of treatment, time of antimicrobial infusion, surgeries, central venous catheters, intra-arterial puncture, mechanical ventilation, serum creatinine, microbiological culture results and minimum inhibitory concentration (MIC). The cultures were obtained from biological specimens (blood, urine, catheter tip, lung, skin, eye and ear secretions). When not available in the medical records, the height and BMI of children were estimated from the anthropometric data available at the National Center for Health Statistics of the Centers for Disease Control and Prevention. ${ }^{(8)}$

The other variables of interest were obtained by equations involving creatinine clearance (CrCL), trough (Cmin), pharmacokinetic profile, $\mathrm{Vd}$, elimination constant (Kel), antimicrobial half-life time $\left(\mathrm{T}_{1 / 2}\right)$, and vancomycin clearance $(\mathrm{CL}) .^{(9)}$

Renal clearance was estimated using the formula of Schwartz et al., ${ }^{(10)}$ according to the equation 1 :

$$
\mathrm{CLcr}=(\mathrm{HxK}) / \mathrm{Scr} \quad(\text { Equation } 1)
$$

Where: $\mathrm{H}$ is height $(\mathrm{cm})$; Scr is serum creatinine $(\mathrm{mg} / \mathrm{dL}) ; \mathrm{K}$ is constant related to age group and sex $(\mathrm{K}$ : 0.45 children $<1$ year; K: 0.55 children ( $1-12$ years) and female adolescents; K: 0.70 male adolescents).

The Cmin and vancomycin Kel were determined from equation 2

$$
\mathrm{Kel}=(\operatorname{lnC} 1-\ln C 2) /\left(\mathrm{T}_{1}-\mathrm{T}_{2}\right) \quad(\text { Equation } 2)
$$

Where: $\mathrm{C}_{1}$ is the natural logarithm of the plasma concentration of the first sample; $\mathrm{C}_{2}$ is the natural logarithm of the plasma concentration of the second sample; $T_{1}$ is the time of first blood sample; and $T_{2}$ is the time of the second blood sample in relation to $\mathrm{Cmin}$.

Equation 3 shows the determination of half-life of the antimicrobial $\mathrm{T}_{1 / 2}$ :

$$
\mathrm{T}_{1 / 2}=0.693 / \mathrm{Kel} \quad \text { (Equation 3) }
$$

Equation 4 shows the Vd:

$\mathrm{Vd}=\operatorname{dose}^{*}\left(\mathrm{e}^{-\mathrm{KT}}\right) / \operatorname{trough}^{*}\left(1-\mathrm{e}^{-\mathrm{KT}}\right) \quad($ Equation 4$)$

Equation 5 shows the antimicrobial clearance:

$$
\mathrm{CL}=\mathrm{Vd}^{*} \mathrm{Kel} \quad(\text { Equation } 5)
$$


The area under the curve (AUC) of vancomycin was obtained using the software BestDose ${ }^{\mathrm{TM}}$, which is a clinical tool that uses non-parametric, multiple-model Bayesian adaptive control to calculate doses that achieve desired goals, such as serum drug concentration. ${ }^{(11)}$

The vancomycin efficacy prediction parameter considered for this study was the ratio of the AUC within 24 hours and the MIC above 400 (AUC $\left.{ }_{0-24} / \mathrm{MIC}>400\right){ }^{(6)}$ and trough values between 10 to $15 \mu \mathrm{g} / \mathrm{mL} .^{(12,13)}$

Respecting the interval of five biological half-lives of vancomycin, on the third day of treatment, two blood samples were collected at different times, with a minimum interval of 2 hours between them $(2 \mathrm{~mL} /$ collection in a sodium and EDTA Vacutainer ${ }^{\circledR}$ tube) and duly identified. The samples were sent to the Laboratory of Toxicology of the Universidade Federal de São João del Rei, where they were centrifuged for 15 minutes at 3,500rpm. A total of $500 \mu \mathrm{L}$ of plasma was removed and stored in conical Eppendorf tubes. The samples were frozen at $-80^{\circ} \mathrm{C}$ in a freezer (FORMA TM 88000 Series $-86^{\circ} \mathrm{C}$ upright ultra-low temperature freezers) until the analysis was carried out, not exceeding 6 months.

The determination of vancomycin concentration in biological matrix (plasma) was conducted using a high performance liquid chromatograph (Agilent Technologies, model 1206), ChemStation for LC 3D systems software (Agilent Technologies ${ }^{\circledR}$, USA), LiChroCART $^{\circledast}$ Purospher (MERCK ${ }^{\circledast}$ C18), and 250mm per $4 \mathrm{~mm}$ reversed phase column. The mobile phase was prepared daily from the mixture of ultrapure (UP) water and acetonitrile (9:1, v/v) added to $27 \mathrm{~g}$ of potassium phosphate monobasic USP $\mathrm{KH}_{2} \mathrm{PO}_{4}$. The hydrogen potential $(\mathrm{pH})$ of the solution was adjusted with hydrochloric acid to 3.0.

The injection volume for the analytical run was $40 \mu \mathrm{L}$, and the effluent was monitored by an ultraviolet detector at $240 \mathrm{~nm}$. A 7-minute run time was required to detect the analyte and its internal standard (ceftriaxone), using the following concentration gradients: time 0 , $100 \%$ mobile phase; from 2 to 5 minutes, $5 \%$ acetonitrile and $10 \%$ methanol were added to the mobile phase; from 5 to 7 minutes, returned to $100 \%$ mobile phase for stabilization.

The analyses were conducted at room temperature $\left(20 \pm 1^{\circ} \mathrm{C}\right)$. The daily calibration curve consisted of 8 points ranging from 2 to $100 \mu \mathrm{g} / \mathrm{mL}$. Internal controls were prepared at high quality control (HQC) concentrations $(80.0 \mu \mathrm{g} / \mathrm{mL})$, medium quality control (MQC; $25.0 \mu \mathrm{g} / \mathrm{mL}$ ), and low-quality control (LQC; $3.0 \mu \mathrm{g} / \mathrm{mL}$. The plasma analyte was quantified based on the daily calibration curve, accepted by HQC, MQC and LQC.
Protein precipitation with acetonitrile was carried out for vancomycin purification in biological matrix, adding $200 \mu \mathrm{L}$ of plasma and $600 \mu \mathrm{L}$ of acetonitrile into a 1.5mL Eppendorf tube.

The samples were stirred in a vortex for 15 seconds, subjected to 8,000rpm, and refrigerated centrifugation at $4^{\circ} \mathrm{C}$, for 30 minutes. After protein precipitation, the samples were concentrated by evaporation in nitrogen flow in a sample concentrator at $40^{\circ} \mathrm{C}$. The residue of the dry extract was dissolved in a solution with $100 \mu \mathrm{L}$ of UP water and acetonitrile in a ratio of $(9: 1, \mathrm{v} / \mathrm{v})$, and the volume was transferred to microvials. The analytical method presented good linearity $\left(\mathrm{r}^{2}=0.99\right)$, precision of 0.10 to 3.90 , accuracy of 90.69 to 120.53 , lower quantification limit of $2 \mu \mathrm{g} / \mathrm{mL}$, and limit of detection of $1.0 \mu \mathrm{g} / \mathrm{mL}$.

To estimate the ideal antimicrobial vancomycin dose, BestDose ${ }^{\mathrm{TM}}$ software and the equation suggested by Winter ${ }^{(9)}$ (Equation 6) were used.

desired $\mathrm{C}^{\mathrm{ss}}=\left(\right.$ desired dose $\times$ current $\left.\mathrm{C}^{\mathrm{ss}}\right) /$ current dose (Equation 6)

Where: $\mathrm{C}^{\mathrm{ss}}$ is the concentration at steady state.

In order to estimate the vancomycin dose adjustment using the BestDose ${ }^{\mathrm{TM}}$ software, the defined dose interval was of 6 hours, with 60 -minute infusion time, 7-day antimicrobial therapy duration, and MIC of $1 \mu \mathrm{g} / \mathrm{mL}$. The peak concentration in the second hour was $30 \mu \mathrm{g} / \mathrm{mL}$, and the trough concentration in the sixth hour was $10 \mu \mathrm{g} / \mathrm{mL}$.

Descriptive statistical analysis was conducted using medians, and dispersion, by an Excel spreasheet.

\section{RESULTS}

Ten pediatric patients on vancomycin 10 to $20 \mathrm{mg} / \mathrm{kg} / \mathrm{dose}$, median age of 5.5 years and interquartile range (IQR) of 3.2 to 9.0 years; median weight of $21 \mathrm{~kg}$ and IQR of 15.5 to $24.0 \mathrm{~kg}$; and median height of $112.5 \mathrm{~cm}$ and IQR of 95 to $133 \mathrm{~cm}$ were included. Six $(60 \%)$ participants were admitted to the intensive care unit, and 4 (40\%) to the wards. The conditions leading to hospitalization were community acquired pneumonia (30\%), cystic fibrosis $(20 \%)$, bacterial pneumonia $(10 \%)$, pulmonary sepsis $(10 \%)$, bacterial meningitis $(10 \%)$, craniectomy (10\%), and septic shock (10\%). The association between vancomycin and meropenem was found in four cases (40\%). The individual characteristics of these children are shown in table 1. 
Table 1. Anthropometric data and individual characteristics of the children

\begin{tabular}{|c|c|c|c|c|c|c|c|c|}
\hline Children (10) & $\operatorname{Sex}(M / F)$ & Age (years) & Weight (kg) & Height (cm) & BMI $\left(\mathrm{kg} / \mathrm{m}^{2}\right)$ & $\mathrm{SCr}(\mathrm{mg} / \mathrm{dL})$ & $\mathrm{CrCl}$ (mL/min) & Wounds (yes/no) \\
\hline 1 & $\mathrm{~F}$ & 12 & 31 & 149 & 13.96 & 0.67 & 122.31 & No \\
\hline 2 & $\mathrm{~F}$ & 2 & 12.6 & 85 & 16.63 & 0.42 & 111.3 & Yes \\
\hline 3 & $M$ & 11 & 60 & 144 & 28.93 & 0.45 & 176 & Yes \\
\hline 4 & $M$ & 12 & 25.1 & 149 & 11.3 & 0.48 & 170.72 & No \\
\hline 5 & $\mathrm{M}$ & 10 & 24.1 & 139 & 12.47 & 0.41 & 186.46 & No \\
\hline 6 & $M$ & 5 & 18 & 110 & 14.87 & 0.22 & 275 & No \\
\hline 7 & $M$ & 3 & 15 & 95 & 16.62 & 0.20 & 261.25 & Yes \\
\hline 8 & $M$ & 3 & 17 & 95 & 18.88 & 0.11 & 475 & Yes \\
\hline 9 & $\mathrm{~F}$ & 6 & 24 & 115 & 18.14 & 0.37 & 170.94 & No \\
\hline 10 & M & 3 & 17 & 95 & 15.51 & 0.22 & 237.50 & Yes \\
\hline Patients & $3 / 7$ & NAP & NAP & NAP & NAP & NAP & NAP & $6(60 \%) / 4(40 \%)$ \\
\hline Median & - & 5.5 & 21 & 112.5 & 16.06 & 0.41 & 181.23 & - \\
\hline Interquartile $25 \%$ - $75 \%$ & - & $3.9-9.0$ & $15.5-24.0$ & $95-133$ & $14.1-17.7$ & $0.22-0.42$ & $170.7-255.3$ & - \\
\hline$V \min -V \max$ & - & $2-12.1$ & $12.6 / 60$ & $85 / 149$ & $11.3 / 28.9$ & $0.11 / 0.67$ & $111.3 / 475$ & - \\
\hline
\end{tabular}

M: male; F: female; BMI: body mass index; SCr: serum creatinine; CrCl: creatinine clearance; NAP: not applicable; Vmin: minimum value; Vmax: maximum value.

The biological half-life of vancomycin in child number 3 is considerably increased $\left(\mathrm{T}_{(1 / 2) \mathrm{B}} 37.7\right.$ hours), as compared to other children; clearance, Kel and $\mathrm{Vd}$ were reduced. The child was obese and the dose used was based on recommendations for adults, as shown in table 2.

Table 2. Pharmacokinetic parameters of vancomycin in children

\begin{tabular}{|c|c|c|c|c|c|}
\hline \multirow{2}{*}{ Children $(n=10)$} & \multirow{2}{*}{$\begin{array}{c}\text { Trough } \\
\text { Cmin }{ }_{(\mu \mathrm{g} / \mathrm{mL})}\end{array}$} & \multicolumn{4}{|c|}{ Pharmacokinetic parameters } \\
\hline & & $T_{(1 / 2) \beta(h)}$ & $\mathrm{CL}_{\mathrm{T}(\mathrm{mL} / \mathrm{min})}$ & $\mathrm{Kel}_{(\mathrm{h}-1)}$ & Vd (L/kg) \\
\hline 1 & 2.76 & 4.17 & 2.61 & 0.23 & 0.67 \\
\hline 2 & 14.3 & 9.48 & 0.29 & 0.10 & 0.17 \\
\hline 3 & 22.6 & 37.7 & 0.01 & 0.02 & 0.04 \\
\hline 4 & 3.85 & 4.31 & 2.79 & 0.22 & 0.76 \\
\hline 5 & 4.82 & 4.37 & 2.23 & 0.22 & 0.60 \\
\hline 6 & 2.69 & 4.37 & 4.06 & 0.22 & 1.10 \\
\hline 7 & 5 & 4.37 & 1.43 & 0.22 & 0.39 \\
\hline 8 & 2.68 & 2.98 & 3.64 & 0.32 & 0.67 \\
\hline 9 & 3.66 & 1.93 & 2.17 & 0.49 & 0.26 \\
\hline 10 & 4.4 & 7.78 & 1.24 & 0.12 & 0.60 \\
\hline Median & 4.12 & 4.37 & 2.20 & 0.22 & 0.60 \\
\hline Interquartile $25-75 \%$ & $2.98-4.95$ & $4.20-6.93$ & $1.29-2.65$ & $0.14-0.27$ & $0.29-0.66$ \\
\hline$V \min / \max$ & $2.68 / 22.6$ & $1.93 / 37.7$ & $0.019 / 4.06$ & $0.02 / 0.49$ & $0.04 / 1.10$ \\
\hline
\end{tabular}

Cmin: minimum trough concentration; (1/2) B: biological half-life; CL: clearance total; Kel: elimination constant; $\mathrm{Vd}$ : volume of distribution.

For the PK and pharmacodynamic (PD) correlation of vancomycin. the individual values are shown in table 3. The MIC found in the results of cultures of biological material for vancomycin, issued by the pediatric hospital
Table 3. Pharmacodynamic profile of the study population for vancomycin

\begin{tabular}{|c|c|c|c|c|}
\hline \multirow{2}{*}{ Children $(n=10)$} & \multicolumn{4}{|c|}{ AUC $_{0-24}^{\text {ss }} / \mathrm{MIC}>400$} \\
\hline & AUC & $0,5 \mu \mathrm{g} / \mathrm{mL}$ & $1 \mu \mathrm{g} / \mathrm{mL}$ & $2 \mu \mathrm{g} / \mathrm{mL}$ \\
\hline 1 & 232 & 464 & 232 & 116 \\
\hline 2 & 523 & 1046 & 523 & 261.5 \\
\hline 3 & 308 & 616 & 308 & 154 \\
\hline 4 & 322 & 644 & 322 & 161 \\
\hline 5 & 385 & 770 & 385 & 192.5 \\
\hline 6 & 362 & 724 & 362 & 181 \\
\hline 7 & 250 & 500 & 250 & 125 \\
\hline 8 & 200 & 400 & 200 & 100 \\
\hline 9 & 382 & 764 & 382 & 191 \\
\hline 10 & 295 & 590 & 295 & 147.5 \\
\hline Median & 315 & 630 & 315 & 157.5 \\
\hline Interquartile $25-75 \%$ & $261.2-377$ & $522.5-754$ & $261.2-377$ & $130.6-188.5$ \\
\hline$V \min / \max$ & $200 / 523$ & 400/1046 & $200 / 523$ & $100 / 261.5$ \\
\hline
\end{tabular}

laboratory participating in this study, ranged from 0.5 to $2 \mu \mathrm{g} / \mathrm{mL}$. When the MIC of $0.5 \mu \mathrm{g} / \mathrm{mL}$ was used, $100 \%$ of patients had effective vancomycin concentrations, whereas for MIC of $1 \mu \mathrm{g} / \mathrm{mL}$, only one child achieved the therapeutic target; for MIC of $2 \mu \mathrm{g} / \mathrm{mL}$, no child $(0 \%)$ using vancomycin achieved the therapeutic target. Empirical treatment was initiated before having the culture results; however, three (30\%) children had Gramnegative bacilli and were also on another antimicrobial to treat Gram-negative infection. The Gram-negative bacilli isolated were Pseudomonas sp in child 2, Gramnegative bacilli in child 3, and Acinetobacter sp in child 8 . 
Staphylococcus aureus was isolated in four (40\%) children, in blood cultures and pulmonary secretion. Staphylococcus xylosus was isolated in child 9. Out of ten children participating in the study, no bacteria were isolated in the culture of two $(20 \%)$ children. The MIC of Staphylococcus aureus ranged from 0.5 and $2.0 \mu \mathrm{g} / \mathrm{mL}$.

For each empirical dose regimen of vancomycin used in the children included in the study, dose adjustment was proposed using BestDose ${ }^{\mathrm{TM}}$ and guidelines for dose regimen suggested by Winter, according to table 4 . Doses of $600 \mathrm{mg}$ and $841 \mathrm{mg}$ (median) were suggested to achieve the therapeutic target.

Table 4. Empirical daily dose regimen of vancomycin versus adjusted dose suggested by BestDose ${ }^{\mathrm{TM}}$ and Winter

\begin{tabular}{|c|c|c|c|c|c|c|}
\hline $\begin{array}{l}\text { Children } \\
(n=10)\end{array}$ & $\begin{array}{l}\text { Empirical } \\
\text { dose }\end{array}$ & $\begin{array}{c}\text { Frequency } \\
\text { between } \\
\text { doses } \\
\text { (hour) }\end{array}$ & $\begin{array}{l}\text { Infusion } \\
\text { time }\end{array}$ & $\begin{array}{c}\text { Dose } \\
\text { per hour } \\
\text { (mg) }\end{array}$ & $\begin{array}{c}\text { BestDose }^{\mathrm{TM} *} \\
\text { Dose per } \\
\text { hour (mg) }\end{array}$ & $\begin{array}{l}\text { Winter** } \\
\text { Dose per } \\
\text { hour (mg) }\end{array}$ \\
\hline 1 & $10 \mathrm{mg} / \mathrm{kg}$ & $6 / 6$ & 1 hour & 310 & 600 & 1,122 \\
\hline 2 & $10 \mathrm{mg} / \mathrm{kg}$ & $6 / 6$ & 1 hour & 126 & 100 & 87.7 \\
\hline 3 & $8.4 \mathrm{mg} / \mathrm{kg}$ & $6 / 6$ & 1 hour & 500 & 950 & 381 \\
\hline 4 & $15 \mathrm{mg} / \mathrm{kg}$ & $6 / 6$ & 1 hour & 376 & 800 & 977 \\
\hline 5 & $15 \mathrm{mg} / \mathrm{kg}$ & $6 / 6$ & 1 hour & 362 & 600 & 749 \\
\hline 6 & $15.3 \mathrm{mg} / \mathrm{kg}$ & $6 / 6$ & 1 hour & 275 & 470 & 1,020 \\
\hline 7 & $10 \mathrm{mg} / \mathrm{kg}$ & $6 / 6$ & 1 hour & 150 & 300 & 300 \\
\hline 8 & $15 \mathrm{mg} / \mathrm{kg}$ & $6 / 6$ & 1 hour & 250 & 800 & 932 \\
\hline 9 & $20 \mathrm{mg} / \mathrm{kg}$ & $6 / 6$ & 1 hour & 480 & 730 & 1,309 \\
\hline 10 & $10 \mathrm{mg} / \mathrm{kg}$ & $6 / 6$ & 1 hour & 150 & 250 & 339 \\
\hline Median & 12.5 & - & 1 hour & 292.50 & 600 & 841 \\
\hline $\begin{array}{l}\text { Interquartile } \\
25-75 \%\end{array}$ & $10-15$ & - & 1 hour & $175-372.8$ & $342-782.50$ & $349-966$ \\
\hline Vmin/Nmax & $8.4 / 20$ & - & $1 / 1$ & $126 / 500$ & $100 / 950$ & $87 / 1,309$ \\
\hline
\end{tabular}

${ }^{*}$ Considering BestDose ${ }^{\mathrm{TW}}$ : frequency of 6 hours, MIC of $2 \mathrm{mg} / \mathrm{L}$, time of therapy 7 days, peak concentration of $30 \mu \mathrm{g} /$ $\mathrm{mL}$ in the second hour and trough of $10 \mathrm{ug} / \mathrm{mL}$ in the sixth hour. ${ }^{* *}$ Considering the formula according to Winter et al. $1{ }^{19}$ desired concentration $(10 \mu \mathrm{g} / \mathrm{mL})=($ desired dose $) \times\left(\right.$ current $\mathrm{C}^{\text {ss }}$ current $) /$ current dose

\section{DISCUSSION}

Uncertainty regarding the use of efficacy parameters and therapeutic levels in children is still a reality. Children have not fully benefited from treatment and understanding of medication toxicity in the clinical progression of infection. ${ }^{(14,15)}$ Recommendations for using vancomycin have undergone major changes over the years; yet, further studies are required to demonstrate evidence of efficacy of antimicrobial therapeutic monitoring in children. ${ }^{(14,16)}$ The present study showed the empirical doses of vancomycin administered in children were unable to guarantee microbiological efficacy for both the Cmin (trough) and AUC/MIC parameters for MICs of 1 and $2 \mathrm{mg} / \mathrm{L}$. Although the empirical doses used follow the recommendations of guidelines, according to Ye et al., ${ }^{(17)}$ the therapeutic monitoring of vancomycin is associated with higher clinical efficacy rates in patients with Gram-positive infections. A recent review by Alves et al., ${ }^{(18)}$ stated that in addition to dose individualization, the use of initial doses of vancomycin $>60 \mathrm{mg} / \mathrm{kg} /$ day is also necessary to obtain effective concentrations of the drug. ${ }^{(2)}$

These findings reinforce the difficulty of establishing an empirical dose for children, and it is necessary to develop models that take into account the many characteristics of this population. In addition, these findings also indicate the need for therapeutic monitoring of vancomycin, and should be a matter of concern regarding the use of antimicrobials in pediatric units, since the doses should be adjusted according to the profile of each child, to obtain an adequate therapeutic response. ${ }^{(2)}$

Regarding the microbiological efficacy profile of vancomycin, there are two parameters available and currently used: the therapeutic ranges for trough and the PK/PD correlation. According to Rybak et al., ${ }^{(6)}$ trough concentrations between 10 and $20 \mu \mathrm{g} / \mathrm{mL}$ are determined to reflect an AUC/MIC >400 in adults. It is therefore preferable, when possible, to measure the PK/PD. In our study this knowledge is extremely important for clinical practice, and presents a very relevant implication. In other words, it is observed that in patients presenting baseline concentrations within and above the therapeutic range established by the formula suggested by Winter et al., ${ }^{(9)}$ which takes into account the desired trough, would need of the dose reduction. On the other hand, when analyzing the $\mathrm{PK} / \mathrm{PD}$ correlation for these same subjects, the therapeutic target was not achieved for MIC of 1 and $2 \mu \mathrm{g} / \mathrm{mL}$, and the dose administered had to be increased, according to the estimate of dose adjustment provided by the software BestDose ${ }^{\mathrm{TM}}$.

Another important finding in our study when we considered the serum concentration of vancomycin in the trough was that an obese child (number 3 ) presented serum trough levels greater than $20 \mu \mathrm{g} / \mathrm{mL}$, using a dose of $8.4 \mathrm{mg} / \mathrm{kg}$; however, they did not achieve serum levels to maintain $\mathrm{AUC}^{\mathrm{SS}}{ }_{0-24} / \mathrm{MIC}>400$. Zhao et al., ${ }^{(19)}$ reported weight and renal function have a significant impact on the PK of vancomycin in children, because the clearance of both vancomycin and creatinine is increased in direct proportion to body weight. Population models that take into account the age, weight and clinical conditions of the pediatric population must be developed and made available for clinical practice. 
Although the BestDose ${ }^{\mathrm{TM}}$ software is based on the American pediatric population, it was developed to be used specifically in children; dose estimation is suggested according to the individual profile of the formula suggested by Winter et al. ${ }^{(9)}$ Using BestDose ${ }^{\mathrm{TM}}$ software, the most appropriate dose can still be adapted so that vancomycin concentrations remain within the trough and AUC parameters. Therefore, due to the lack of an instrument for dose adjustment for the Brazilian population, or even the lack of therapeutic drug monitoring services in health organizations in Brazil, BestDose $^{\text {TM }}$ is a reliable tool for dose adjustment in children. There are no population models of vancomycin in the pediatric population in Brazil. ${ }^{(2,20,21)}$

Much has been argued in relation to toxicity, mainly with the use of vancomycin. In our study, some endpoints, such as nephrotoxicity, were not evaluated. A study by Cole et al., ${ }^{(16)}$ found that the scientific evidence on vancomycin nephrotoxicity is associated with the concurrent use of other nephrotoxic drugs, especially in critically ill children on polypharmacy. For Ye et al., ${ }^{(17)}$ therapeutic monitoring of vancomycin is associated with lower nephrotoxicity rates.

This study has the limitation of a small sample of children who met the inclusion criteria in the period. In addition, during this period, data on adverse events related to the use of vancomycin were not recorded.

\section{CONCLUSION}

The empirical use of vancomycin in the studied population did not achieve the therapeutic pharmacokinetic and pharmacodynamics target for minimum inhibitory concentration in most cases, and dose adjustment was necessary. These findings highlight the importance of implementing therapeutic monitoring of vancomycin in severely ill children, with potential pharmacokinetic changes, aiming to reach the therapeutic target and improve clinical response. This study demonstrated the urgent need of a dose adjustment instrument for the Brazilian pediatric population profile.

\section{ACKNOWLEDGEMENTS}

To the Universidade de Itaúna, for providing laboratories for this study. To the Toxicology Laboratory of the Universidade de São Paulo, namely to Dr. Silvia Regina Santos, for the initial analysis of samples. To Fundação Hospitalar do Estado de Minas Gerais, for the partnership in this work. This study is related to the Graduate Program in Pharmaceutical Sciences of Universidade Federal de São João del Rei.

\section{AUTHORS' INFORMATION}

Alves GC: http://orcid.org/0000-0002-2023-8011

Chequer FM: http://orcid.org/0000-0002-0764-6918

Sanches C: http://orcid.org/0000-0002-8562-1337

\section{REFERENCES}

1. Scott JA, Wonodi C, Moïsi JC, Deloria-Knoll M, DeLuca AN, Karron RA, Bhat N, Murdoch DR, Crawley J, Levine OS, O'Brien KL, Feikin DR; Pneumonia Methods Working Group. The definition of pneumonia, the assessment of severity, and clinical standardization in the Pneumonia Etiology Research for Child Health study. Clin Infect Dis. 2012;54(Suppl 2):109-16. Review.

2. Gomez DS, Campos EV, de Azevedo RP, Silva JM Jr, Ferreira MC, SanchesGiraud C, et al. Individualised vancomycin doses for paediatric burn patients to achieve PK/PD targets. Burns. 2013;39(3):445-50.

3. Santos SR, Sanches-Giraud C, Vieira Jr C, Souza FF, Gómez DS, Campos EV, et al. Pharmacokinetic-pharmacodynamic correlation for meropenem applied to a burn child using a bioanalytical liquid cromatographic method. Rev Port Farmacoter. 2011;3:224-32.

4. Downes KJ, Hahn A, Wiles J, Courter JD, Vinks AA. Dose optimisation of antibiotics in children: application of pharmacokinetics/pharmacodynamics in paediatrics. Int J Antimicrob Agents. 2014;43(3):223-30. Review.

5. Barker $\mathrm{Cl}$, Standing JF, Turner MA, McElnay JC, Sharland M. Antibiotic dosing in children in Europe: can we grade the evidence from pharmacokinetic/ pharmacodynamic studies - and when is enough data enough? Curr Opin Infect Dis. 2012;25(3):235-42. Review.

6. Rybak MJ, Lomaestro BM, Rotschafer JC, Moellering RC Jr, Craig WA, Billeter $\mathrm{M}$, et al. Therapeutic monitoring of vancomycin in adult's summary of consensus recommendations from the American Society of Health-System Pharmacists, the Infectious Diseases Society of America, and the Society of Infectious Diseases Pharmacists. Pharmacotherapy. 2009;29(11):1275-9. Review.

7. Silva P. Farmacologia. 8a ed. Rio de Janeiro: Guanabara Koogan; 2010. p. 27

8. Centers for Disease Control and Prevention (CDC). About antimicrobial resistance [Internet]. Atlanta: CDC; 2017 [cited 2018 Feb 16]. Available from: http://www.cdc.gov/drugresistance/about.html

9. Winter ME, Ambrose PJ. Vancomycin. In: Winter ME. Basic clinical Pharmacokinetics. Philadelph: Lippicortt; 2004. p. 45-76.

10. Schwartz GJ, Haycock GB, Edelmann CM Jr, Spitzer A. A simple estimate of glomerular filtration rate in children derived from body length and plasma creatinine. Pediatrics. 1976;58(2):259-63.

11. Laboratory of Applied Pharmacokinetics and Bioinformatics (LAPKB). Optimizing drug therapy for populations and individuals [Internet]. Los Angeles: LAPKB; 2017 [cited 2017 May 5]. Available from: http://www.lapk. org/bestdose.php

12. Ye ZK, Chen YL, Chen K, Zhang XL, Du GH, He B, Li DK, Liu YN, Yang KH, Zhang YY, Zhai SD; Guideline Steering Group, the Guideline Development Group and the Guideline Secretary Group. Therapeutic drug monitoring of vancomycin: a guideline of the Division of Therapeutic Drug Monitoring, Chinese Pharmacological Society. J Antimicrob Chemother. 2016;71(11):3020-25.

13. Liu C, Bayer A, Cosgrove SE, Daum RS, Fridkin SK, Gorwitz RJ, Kaplan SL, Karchmer AW, Levine DP, Murray BE, J Rybak M, Talan DA, Chambers HF; Infectious Diseases Society of America. Clinical practice guidelines by the infectious diseases society of america for the treatment of methicilinresistant staphylococcus aureus infections in adults and children. Clin Infect Dis. 2011;52(3):e18-55. Erratum in: Clin Infect Dis. 2011;53(3):319.

14. Macleod S, Carleton B. Pharmacological research involving children and adolescents: the Canadian context. In: Avard D, Samuel J, Knoppers BM, editors. Pediatric Research in Canada. Montreal: Les Éditions Thémis; 2009. p. 161-87. 
15. Kearns GL, Reed MD. Immediate action needed to improve labeling of prescription drugs for pediatric patients. Ann Pharmacother. 1997;31(2): 249-51.

16. Cole TS, Riordan A. Vancomycin dosing in children: what is the question? Arch Dis Child. 2013;98(12):994-7. Review.

17. Ye ZK, Tang HL, Zhai SD. Benefits of therapeutic drug monitoring of vancomycin: a systematic review and meta-analysis. PLoS One. 2013;8(10):e77169. Review.

18. da Silva Alves GC, da Silva SD, Frade VP, Rodrigues D, Baldoni AO, de Castro WV, et al. Determining the optimal vancomicyn daily dose for pediatrics: a meta-analysis. Eur J Clin Pharmacol. 2017;73(11):1341-53. Review.
19. Zhao W, Zhang D, Fakhoury M, Fahd M, Duquesne F, Storme T, et al. Population pharmacokinetics and dosing optimization of vancomycin in children with malignant hematological disease. Antimicrob Agents Chemother. 2014;58(6):3191-9.

20. Eiland LS, English TM, Eiland EH 3rd. Assessment of vancomycin dosing and subsequent serum concentrations in pediatric patients. Ann Pharmacother. 2011;45(5):582-9.

21. Frymoyer A, Hersh AL, Coralic Z, Benet LZ, Joseph GB. Prediction of vancomycin pharmacodynamics in children with invasive methicillin-resistant staphylococcus aureus infections: a Monte Carlo simulation. Clin Ther. 2010;32(3):534-42. 